\title{
Aphonia with Unknown Etiology: A Case Report
}

\author{
Afonia com Etiologia Desconhecida: Relato de Caso
}

\author{
Valeriana de Castro Guimaraes*, Paulo Humberto Siqueira**, Victor Labres da Silva Castro ***, \\ Maria Alves Barbosa $* * * *$, Celmo Celeno Porto $* * * *$.
}

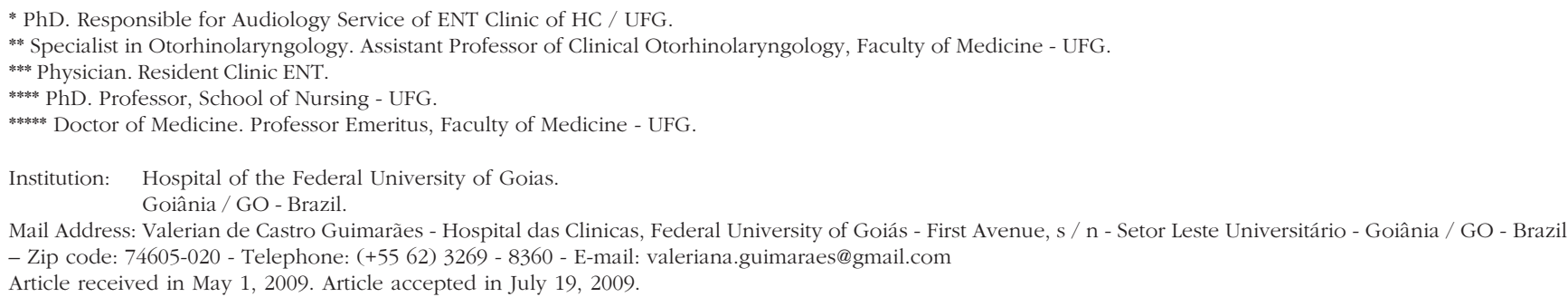

\section{SUMMARY}

Introduction:

Objective:

Case Report:

Final Comments:

Keywords:

\section{RESUMO}

Introdução:

Objetivo:

Relato do Caso:

Comentários Finais:

Palavras-chave:
The conversion aphonia is defined as the total loss of voice, is a rare disease that often affects women. The diagnosis is clinical, because there are no changes in the laryngeal structures.

To describe a case of conversion aphonia, seen in a public hospital in the Midwest of Brazil. Patient 32 years old female, complaining of hoarseness for two days without other apparent symptoms. The examinations revealed no changes in the laryngeal structures and / or extra laryngeal. Stages of care have been described since the initial consultation to the recovery of the patient.

It is important to consider the psycho-emotional aspects involving patients with voice disorders since they may cause or modify the symptoms and affect the prognosis.

aphonia, hoarseness, laryngeal diseases, stress, voice.

A afonia de conversão é definida como a perda total da voz, é uma doença rara que acomete frequentemente as mulheres. O diagnóstico é clínico, pois não há alterações nas estruturas laríngeas. Descrever um caso de afonia de conversão, atendida em um hospital público no Centro-Oeste do Brasil.

Paciente de 32 anos, sexo feminino, com queixa de afonia há dois dias, sem outros sintomas aparentes. Os exames não revelaram alterações nas estruturas laríngeas e/ou extralaríngeas. As etapas do atendimento foram descritas desde a consulta inicial até a recuperação da paciente.

É importante considerar os aspectos psicoemocionais que envolvem os pacientes com alterações vocais, uma vez que os mesmos podem originar ou alterar os sintomas e comprometer o prognóstico da doença.

afonia, rouquidão, doenças da laringe, estresse, voz. 


\section{INTRODUCTION}

In recent years there has been a growing increase in studies of conversion disorders, such interest has been provided by developments in neuroscience, especially in jobs involving brain imaging (1).

The conversion disorders occur when there is a somatic, or psychological or psychic mechanism is expressed in the form of physical symptoms (2), among which the bodies of the larynx may be affected.

The larynx is a cartilaginous structure with muscle specific function of producing sound in phonation, respiration and sphincter function. Being a sensible structure, the larynx becomes more vulnerable to various diseases, which worsens over the face of risk factors as smoking and alcohol consumption (3).

Generally, the initial signs of a throat problem arise in the form of a voice disorder. Multifactorial origin dysphonia presents itself as any changes in voice due to a functional disorder and/ or dysfunction of the vocal tract, being the most common form of vocal disorders. Overuse and inappropriate voice is an important example of a cause of dysphonia $(3,4)$.

The psycho-emotional disorders can trigger the onset of psychogenic dysphonia related to conversion, the frame being the most common conversion aphonia, defined as the total loss of voice, a disorder that often affects the female gender $(5,6,7)$.

The human voice is unique and allows the individual to communicate with their peers, express thoughts and emotions (3). Sometimes, psychiatric symptoms often manifest themselves on the vocal tract (7).

This paper introduces the presentation of a case, its relevance lies in the fact that this form is unusual in the otorhinolaryngology, possibly by the rarity of its occurrence.

In this report the authors describe a case of aphonia case of conversion seen at Hospital das Clinicas, Federal University of Goiás, in Goiânia.

\section{Case Report}

VCG patient, 32 years old, female, public employee, postgraduate student, single, born in Goiânia (GO) sought the emergency department of Otorhinolaryngology, Hospital das Clinicas, Federal University of Goias HC / UFG in June 2006 with the following clinical features: aphonia two days ago, no other ENT symptoms apparent.

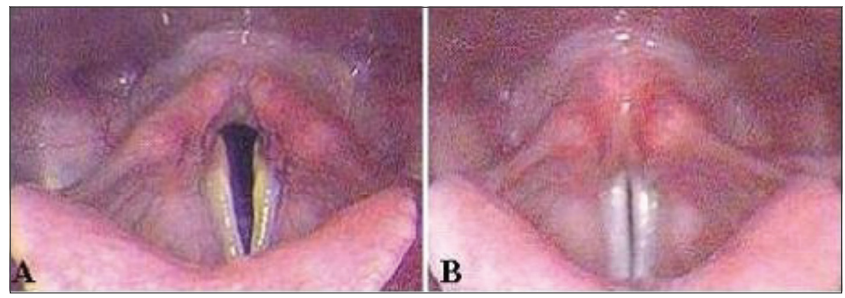

Figure 1. Laryngoscopy. (A) Vocal folds in abdiction (breath). (B) adductor vocal folds (phonation). HC / UFG 2006

Said that in the last six months two episodes of aphonia, looking for a health unit. She was seen by an ENT, who through indirect laryngoscopy showed a slight edema between the arytenoid cartilage, suggestive of laryngopharyngeal reflux. At the time it was prescribed omeprazole $20 \mathrm{mg}$ 12/12h, with clinical improvement of the situation after three / four weeks. He reported further that the vocal came after weeks of stressful and exhausting work, followed by evening classes. It states that in the days before the riots showed no signs or symptoms different, just tired and woke at dawn voiceless.

At evaluation, the patient was in good general condition, afebrile, without signs or symptoms of rhinorrhea and nasal itching. Denies alcoholism, smoking, drug use and abuse of voice.

In the otorhinolaryngological oropharyngoscopy, rinofaringoscopia anterior and otoscopy showed no changes.

Based on the clinical laboratory tests were requested, the results were normal. The procedure of laryngoscopy revealed no organic lesions in the laryngeal structures and / or extralaryngeal (Figure 1).

Diagnosed with psychogenic aphonia, was recommended to abundant water intake, along with voice therapy. The patient was referred to the audiology clinic of the hospital.

Four days after the initial consultation, the patient showed significant improvement in her voice and was instructed to return to the otorhinolaryngology after 30 days. After this period, he returned without signs of aphonia. The patient was discharged and held follow-up speech therapy.

\section{DISCUSSION}

The literature is vast when it comes to vocal disorders, however, the limitation of this study is evidenced by the scarcity of studies that specifically address the 
conversion aphonia, and such data provide support for further studies on the topic.

Experts believe that the persistent hoarseness, coughing, sore throat, pain and difficulty swallowing, difficulty breathing, vocal fatigue and voice loss may be indicative of lesions in the larynx (3). In our case, the examination of laryngoscopy did not visualize changes in the level of the larynx, vocal cords or structures proximal to justify the voice disorder.

As suggested in the literature, the diagnosis of aphonia is basically clinical, since there are no lesions in the organs of the larynx or vocal folds (8). In the case described the laryngeal structures were normal, without lesions.

The case reported it is a female patient. These findings are similar to those described in the literature, where the disease predominantly affects individuals of this genus $(5,6,7,9)$.

Studies show that the presence of gastroesophageal reflux can lead to laryngeal disorders, vocal disorders and consequently (10). Although in early episodes have made use of medications for this condition, the vocal symptoms of the patient remained for weeks

Surveys show the anxiety, depression, interpersonal conflicts, difficulties in expressing feelings or opinions of aphonia as etiological factors $(5,6,7,9,11)$. Contradicting these data, the case presented the patient denies anxiety, depression or some type of trauma, only mentions the daily stress. This being possible triggering factor of aphonia.

Medical management was based on the vocal rehabilitation and increased fluid intake, resulting in significant improvement of the framework. These findings are similar to several studies that indicate therapies vocal determinants for the prompt recovery of patients $(8,12,13)$.

Studies describe cases in which the voice disorder remains for weeks $(9,14)$, in the case presented in only four days the patient had his vocal standard. Due to the rapid improvement of symptoms, the patient was not referred to the psychotherapeutic treatment, as suggested by some studies $(6,8)$.

While advances are evident diagnosis still represents a challenge (1), however, the psychological factor plays an important role and should be considered in the diagnosis and the therapeutic process of patients with vocal disorders (11). The absence of vocal fold lesions, it was considered agitation or daily stress reported by the patient as a possible trigger factor for the inconvenience experienced by the same voice.
Thus it is important to the differential diagnosis aphonia, since psycho-emotional aspects involving the individual may be somatized for laryngeal structures, and all the emotional charge conveyed to the vocal tract, causing the emergence of vocal changes or disturbances (14).

\section{FINAL COMMENTS}

The psychological aspects involving patients should be considered in any trouble, since they may cause or modify symptoms and compromise the prognosis.

The medical history preceding the emergence of a vocal to be raised by experts, enabling appropriate action, considering that reflects the voice and transmits a person's personality.

\section{BibliographicAl REFERENCES}

1. Aybek S, Kanaan RA, David AS. The neuropsychiatry of conversion disorder. Curr Opin Psychiatry. 2008, 21:27580.

2. Hurwitz TA. Somatization and conversion disorder. Can J Psychiatry. 2004, 49:172-8.

3. Guimarães VC, Viana MADESR, Barbosa MA, Paiva MLF, TavaresJAG V, Camargo LA. Cuidados Vocais: questão de prevenção e saúde. Rev C S Col [periódico na internet] 2008 out. [Citado em 10 de dezembro 2008]; [cerca de 5 p.] Está disponível em: http://www.cienciaesaudecoletiva.com.br/

4. Jardim R, Barreto SM, Assunção AA. Condições de trabalho, qualidade de vida e disfonia entre docentes. Cad. Saúde Pública, Rio de Janeiro. 2007, 23:2439-61.

5. Bhatia MS, Vaid L. Hysterical aphonia an analysis of 25 cases. Indian J Med Sci. 2000, 54:335-8.

6. Butcher P. Psychological processes in psychogenic voice disorder. Eur J Disord Commun. 1995, 30:467-74.

7. Tsuruga K, Kobayashi T, Hirai N, Kato S. Foreign accent syndrome in a case of dissociative (conversion) disorder. Seishin Shinkeigaku Zasshi. 2008, 110:79-87.

8. Maniecka-Aleksandrowicz B, Domeracka-Ko3odziej A, Rózak-Komorowska A, Szeptycka-Adamus A. Management and therapy in functional aphonia: analysis of 500 cases. Otolaryngol Pol. 2006, 60:191-7.

9. Kuljiæ B. Cognitive-behavioral therapy of conversion aphonia]. Vojnosanit Pregl. 2004, 61:695-8. 
10. Leuchter I, Monnier P, Brossard E, Schweizer V. Gastroesophageal reflux: a possible cause of paroxysmal laryngeal dyspnea. Rev Med Suisse. 2008, 4:1113-7.

11. Willinger U, Völkl-Kernstock S, Aschauer HN. Marked depression and anxiety in patients with functional dysphonia. Psychiatry Res. 2005, 30:85-91.

12. Du JQ, Yang BQ, Liu JX. Diagnosis and treatment and prevention of iatrogenic functional aphonia.
Zhonghua Er Bi Yan Hou Tou Jing Wai Ke Za Zhi. 2006, 41:641-3.

13. Van Harten PN, Schutte HK. Psychogenic aphonia an effective and rapidly treatable conversion Ned Tijdschr Geneeskd. 1992, 136:790-3.

14. Rubin JS, Greenberg M. Psychogenic voice disorders in performers: a psychodynamic model.J Voice. 2002, 16:5448. 